\title{
Adapting the Surveying Curriculum to New Dimensions of the Profession
}

\author{
Fahria Masum \\ Land Management, Munich \\ Reinfried Mansberger \\ University of Natural Resources and Life Sciences, Vienna \\ Audrey Martin \\ Technological University of Dublin, audrey.martin@tudublin.ie
}

See next page for additional authors

Follow this and additional works at: https://arrow.tudublin.ie/beschrecart

Part of the Civil Engineering Commons, Construction Engineering and Management Commons, Engineering Education Commons, and the Other Civil and Environmental Engineering Commons

\section{Recommended Citation}

Fahria Masum, Reinfried Mansberger, Audrey Martin,Gerhard Navratil, Anthony Mushinge, Adapting the Surveying Curriculum to New Dimensions of the Profession, 2019, Journal of Professional Issues in Engineering Education and Practice, 04019003, V 145, N 2, doi:10.1061/(ASCE)El.1943 5541.0000408

This Article is brought to you for free and open access by the School of Surveying and Construction Management at ARROW@TU Dublin. It has been accepted for inclusion in Articles by an authorized administrator of ARROW@TU Dublin. For more information, please contact arrow.admin@tudublin.ie, aisling.coyne@tudublin.ie, gerard.connolly@tudublin.ie.

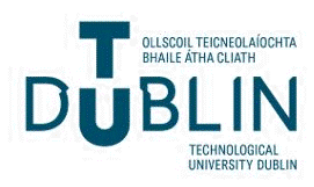




\section{Authors}

Fahria Masum, Reinfried Mansberger, Audrey Martin, Gerhard Navratil, and Anthony Mushinge 


\title{
Adapting the Surveying Curriculum to New Dimensions of the Profession
}

\author{
Fahria Masum, Ph.D. ; Reinfried Mansberger, Ph.D. ${ }^{2}$; Audrey Martin, Ph.D. ${ }^{3}$; \\ Gerhard Navratil, Ph.D. ${ }^{4}$; and Anthony Mushinge, Ph.D. ${ }^{5}$
}

\begin{abstract}
Today the surveying profession is very different from what it was twenty years ago. Recent technological innovations, globalization, and global land-related challenges have allowed a wide range of advances in the surveying profession. The vision is to promote surveying practices that can enhance the quality of services in a variety of tracks in the land profession. According to the new adjacent professional areas and the needs of the labor market, academic courses for surveyors have to be adapted to meet the broader scope of the surveying profession and to supply highly qualified land professionals. This paper outlines the new challenges for the surveying profession and highlights the core skills, competencies, and knowledge that should be highly valued to produce competent experts. Furthermore, this paper suggests a common structure of a surveying curriculum to capture the new academic themes for better adaptation to the broader scope of the surveying profession. DOI: 10.1061/(ASCE)EI.1943-5541.0000408. (C) 2019 American Society of Civil Engineers.
\end{abstract}

\section{Introduction}

Surveying has been traditionally defined as the science and art of determining exact positions of points above, on, or beneath the Earth's surface, or staking out such points. Land surveying is one of the oldest professions in the world, dating back to 1,400 BCE in Egypt, where surveyors were appointed to redefine the boundaries when the annual floods of the Nile swept away portions of the plots divided for the purpose of taxation (Rayner and Buley 1965). Campbell (1747, p. 161) in The London Tradesman defined a land surveyor as

employed in measuring Land, and laying it out in Gardens and other kinds of Policy about gentleman's seats. To have a good taste this Way he ought to travel to France and Italy, and to have a liberal education, but especially a thorough knowledge of Geometry and Designing. They may earn a Guinea a day when employed in laying out, and are always esteemed above a Mechanic.

According to the American Congress on Surveying and Mapping (1978), surveying/land surveying involves the re-establishment of cadastral surveys and land boundaries based on documents of record

${ }^{1}$ Consultant, Land Management, Connollystrasse 26, Munich 80809, Germany (corresponding author). Email: masum@landguidance.com

${ }^{2}$ Assistant Professor, Institute of Surveying, Remote Sensing and Land Information, Univ. of Natural Resources and Life Sciences, Peter Jordanstrasse 82, Vienna A-1190, Austria. Email: mansberger@boku.ac.at

${ }^{3}$ Senior Lecturer, School of Surveying and Construction Management, Dublin Institute of Technology, Bolton St., Dublin D01 K822, Ireland. Email: Audrey.martin@dit.ie

${ }^{4}$ Senior Researcher, Dept. of Geodesy and Geoinformation, Technische Universitaet Wien, Gußhausstr. 27-29/E120, Vienna 1040, Austria. Email: gerhard.navratil@geo.tuwien.ac.at

${ }^{5}$ Lecturer, Dept. of Real Estate Studies, School of the Built Environment, Copperbelt Univ., Jambo Dr., Kitwe 21692, Zambia. Email: anthonymushinge@yahoo.com

Note. This manuscript was submitted on April 11, 2018; approved on October 4, 2018; published online on February 12, 2019. Discussion period open until July 12, 2019; separate discussions must be submitted for individual papers. This paper is part of the Journal of Professional Issues in Engineering Education and Practice, (C) ASCE, ISSN 1052-3928. and historical evidence, as well as certifying surveys (as required by statute or local ordinance) of subdivision plats or maps, registered land surveys, judicial surveys, and space delineation.

In the 18th and 19th centuries, the art of surveying advanced more rapidly. Today the reality of surveying is much more diverse. Previously surveying was mainly about measuring land; today, surveying involves management of land and requires a transdisciplinary approach. With the changing scope of the surveying profession, new definitions of the term surveying were also introduced. The General Assembly of the International Federation of Surveyors (FIG) adopted a definition that describes a surveyor as

a professional person with the academic qualifications and technical expertise to conduct one, or more, of the following activities to determine, measure and represent land, threedimensional objects, point-fields and trajectories; to assemble and interpret land and geographically related information, to use that information for the planning and efficient administration of the land, the sea and any structures thereon; and, to conduct research into the above practices and to develop them. (FIG 2008, p. 10)

Today, surveying is often referred to as geomatics or geoinformatics. Both terms have been relatively recently introduced compared with the ancestor term land surveying, which they are meant to replace (Lemmens 2011). In response, a number of university departments and agency divisions that once had names containing the terms surveying, surveying engineering, or topographic science have been renamed to include terms like geomatics, geomatic science, or geomatic engineering (Labi 2014). Within FIG, the term land professional has been introduced to refer to this broader role of a surveyor (Enemark and Williamson 2004). According to Lemmens (2011), as the possibilities offered by advancement in information processing, (tele)communication, space exploration, and sensor development have dramatically changed working methods, the term land surveyor is no longer adequate to encompass more than just traditional land surveying. However, the definition of surveying or surveyor is still being used, although it is recognized that it may not capture the present and future role of surveyors, which continues to evolve (Masum et al. 2017). 
Surveying, as a discipline, is evolving rapidly and therefore surveying education is facing challenges in regard to curriculum, core competencies, and skills (Masum et al. 2017). Though the evolution of surveying curriculum over the past decades reflected to a great extent the growth and broader scope of the surveying profession, surveying education still needs to adopt the academic themes, which go beyond the technical requirements for the profession. Therefore, this paper seeks to explore the changing perspective of the surveying profession, including the nature of rapid technological advancement. Furthermore, taking into account the required core knowledge, skills, and competencies in response to the changing scope of the surveying profession, the paper presents a discussion about the educational profile that can be incorporated into the new role of surveyors, and what this implies for the future of surveyors as land professionals.

Due to authors' involvement at European universities, the paper is focused on the surveying education in Europe. The authors' experiences in international capacity development projects, as well as the relevant publications of other institutions (e.g., ABET 2017) directed at revising and assessing of curricula, have been considered in the research.

\section{Study Objective and Methodology}

This study considers land professionals in general, and land surveyors in particular, with the knowledge, skills, and competencies necessary to address today's, as well as tomorrow's, needs. It is assumed that academics will benefit from learning a practical, generic, and timeless approach to curriculum development, and its structure, in line with the surveying profession's future vision and mission.

The study is based on desk research into study findings to gain a broad understanding of the changing perspective of the surveying profession and surveying education. It analyzes the curricula of 15 European universities at the bachelor's and master's levels in 12 European countries (Austria, Denmark, England, Finland, Germany, Ireland, the Netherlands, Poland, Scotland, Spain, Sweden, and Switzerland) and classifies the major components of the surveying curriculum. Taking into account the changing scope of the surveying profession, the research identifies the main needs and gaps in the surveying curriculum in Europe.

\section{Changing Perspectives of the Surveying Profession}

The challenges in guaranteeing sustainability of the worlds' resources and well-being have significantly increased in recent decades, as identified in many publications (FAO 2012; HODAI 2016; WEF 2017) and their significance to the surveying profession are summarized in Masum et al. (2017). Many of these global challenges can be incorporated into the United Nations 17 Sustainable Development Goals (SDGs) as identified by the United Nations in 2015 (UN 2017). Meeting these SDGs around the globe depends on significant national policy implementation built on best practice and evidence-based procedures, which will benefit from input from many international organizations and professionals, including surveyors. In particular, the surveying profession and its academic education is well-placed to provide information and expertise to help to achieve the specific SDGs outlined in Table 1.

Spatial information management is an essential pillar of good land management and, with it, an essential ingredient for meeting the global challenges identified in Table 1. In recent decades, surveying and spatial data collection, as well as spatial data management in particular, have undergone a number of significant developments. These developments have been made possible by developing Information Technology (IT), the increasing speed of computer processors, and the accessibility to large banks of spatially related information via the internet. These developments and their impact on the surveying profession are elaborated on in the following sections.

\section{Modern Data Collection Tools and Advancement of Technologies}

The data collection tools and techniques used in the surveying and mapping profession have changed significantly since the introduction of the electronic distance meter (EDM) in the 1960s. The profession, served well by highly trained experts in precise measurement who traditionally used analogue techniques, quickly adapted to the digital theodolites, total stations, and levels introduced in the 1970s, 1980s and 1990s, respectively. Developments in digital data-recording and data-processing hardware and software implemented during this time significantly altered surveying practices and made conventional surveying faster and more accurate, while also expanding the role of the traditional surveyor.

By the mid-1990s, use of global positioning systems (GPSs) had become commonplace among surveying companies, which wholly embraced the capabilities of the system for precise positioning over long distances. More advanced global positioning systems, including Glonass, BeiDou, and Galileo, collectively known as global navigation satellite systems (GNSSs), enabled the establishment of new regional and global three-dimensional (3D) coordinate reference frameworks underpinning survey infrastructure and expanding the boundaries of international cooperation when collecting and distributing spatial data.

Terrestrial and mobile data collection systems, integrated with GNSSs and inertial measurement units (IMUs), now collect data clouds using scanning technologies and can quickly produce

Table 1. UN SDGs of relevance to the surveying profession

\begin{tabular}{ll}
\hline SDG & \multicolumn{1}{c}{ Expertise } \\
\hline Food security & $\begin{array}{l}\text { Secure and equal access to land } \\
\text { Equitable quality education and lifelong learning opportunities for all } \\
\text { Gender equality }\end{array}$ \\
$\begin{array}{ll}\text { Supply qualified teachers, including teacher training in developing countries } \\
\text { Implement reform to ensure equal rights concerning economic resources, land } \\
\text { ownership and other forms of property, financial services, and natural resources } \\
\text { Safe, resilient, and sustainable cities and human settlements }\end{array}$ & $\begin{array}{l}\text { Increase access to information and communications technology } \\
\text { Build capacity for participatory, integrated, and sustainable human } \\
\text { settlement planning }\end{array}$ \\
Climate change and its impacts & $\begin{array}{l}\text { Prepare for and raise awareness of the impacts of climate-related hazards } \\
\text { and natural disasters }\end{array}$ \\
Peaceful societies, access to justice for all, and effective institutions & $\begin{array}{l}\text { Promote equal access to justice for all } \\
\text { Target capacity building in developing countries }\end{array}$ \\
\hline
\end{tabular}


accurate 3D models from dense, feature-rich point clouds. A major driving force of rich and accurate 3D data collection is Scan-toBIM (Building Information Modeling), which has widened the applications of surveying beyond the terrestrial domain and exposed the surveying profession to a wider geospatially aware audience. In addition, homogenous geospatial data sets across professional and land boundaries, including the land-sea interface, can meet some of the societal and environmental challenges as identified in the UN SDGs in Table 1.

The geomatics domain encompasses the study of dynamic changes in the Earth and monitoring changes in both the natural and the built environments. This has been facilitated by advances in the collection of remotely sensed data from an ever increasing number of earth observation (EO) satellites. With the development of aerial laser scanning (ALS) techniques and high-resolution digital aerial cameras, combined with structure from motion (SfM) and new image-matching techniques, national mapping and cadastre agencies (NMCAs) now effectively use aerial photogrammetry as a standard method for large-scale mapping. An explosion in aerial 3D data capture in near real time has resulted from lightweight drone platforms, including remotely piloted aerial systems (RPASs) and unmanned aerial vehicles (UAVs), capable of carrying multiple geocoded measurement sensors. The developments in digital technology data capture and processing provide users with new and imaginative deliverables such 3D models and location-based services in real time. Such data sets can be an effective means of presenting geospatial data fly-through or virtual reality (VR) and augmented reality (AR) to nonspecialist audiences, and thus drive the demand for geospatial data.

\section{Advancement in Data Interoperability and Data Management Systems}

In tandem with the development of new survey technologies, which can capture more spatial data faster than ever before, there is the development of IT and platforms that can store, manage, and manipulate these new huge data sets. The personal computer now hosts a wealth of processing power, which, when coupled with a graphics card, high-capacity storage, and the required software, can create a workstation that meets the mapping requirements of most users. Where more intensive processing power is required, and/or larger data sets are used, connection via the internet to cloud computing can provide surveying and mapping solutions for a wider or more specialized audience. Increasingly, software solutions for the geospatial industry are being performed remotely via the internet either by organizations in different countries and often on different continents or via automatic solutions in the cloud. For example, coordinate solutions for precise point positioning (PPP) from GNSS data are now freely available from the internet, provided that the user sends the data in the correct format. Positioning services such as PPP will become more common with increased internet connectivity via mobile networks, and future high accuracy positioning will be commonplace via dedicated survey applications on smart phones. In this way, the link between communication technologies and IT facilitates a wealth of geospatial solutions at our fingertips. Such geospatial solutions can be realized only if authoritative spatial information can be shared, and services and applications appear seamless regardless of the platform. For such reasons, the development and implementation of standards is crucial to facilitating the globalization of data and services.

Recent data collection methods are faster and entail simplified measurement procedures, enabling a bottom-up approach to mapping that allows nonsurveying professionals to become data collectors. Crowd sourcing geospatial data generally refers to generating a map using informal social networks and web technology (Heipke 2010), which originates from a multitude of sources and increases the potential for geospatial data collection. However, because crowd-sourced data cannot guarantee specific uniform quality for a specific product, it is imperative that data quality be based on purpose or use, currency, relevance, and accuracy and precision; thus it must be "fit for purpose."

At a national level, spatial data and associated attributes are generally maintained in specific databases in a spatial data infrastructure (SDI). Where institutional permissions and standards have been defined, interoperability between various data sets facilitates local and global applications and allows multiple digital deliverables. These deliverables are generally accessed via web-based geoportals built on geographical information systems (GISs), which can facilitate both 3D and 4D data and can enable a collaborative approach between many different disciplines. While many of these geospatial developments are being driven by technological advancements, drivers for geospatial data interoperability and harmonization have been recognized at a policy level, nationally and internationally (ECOSOC 2017).

Innovations in both mapping technology and geospatial tools such as those just outlined can increase success in achieving UN SDGs (Fisher 2015). However, the challenge for the surveyor is in retaining the title of geospatial expert, whether this is in data capture, data manipulation, or data management. Furthermore, the surveyor needs to remain an integral part of integrated processes where geospatial data forms the foundation of evidence and location-based decision making. The role of geospatial expert and substantial partner for land and environmental management can only be held if surveyors are continuously upskilling in the field of information and communication technologies. Otherwise, the role of the surveyor will be restricted to a provider of geodata.

\section{Changing Profile of the Surveying Profession and Its Impact on Professional Education}

As a defined goal in the Bologna Declaration (Bucharest Communique 2012), academic education has to enhance the employability and personal and professional development of graduates throughout their career. Due to the increasing complexity of professional tasks and processes, academic surveying education has to stimulate students to create, connect, and inspire knowledge, skills, and competences (creative intelligence). To meet these challenges, surveying curricula have to be adapted continuously. Academic surveying institutions have to deliver proper training and education to make their graduates fit for purpose and future proof. This can be achieved by continuously updating curricula and by implementing new trends in academic training and providing opportunities for Lifelong learning (LLL).

\section{Changing Professional Roles and Required Professional Competencies}

Masum et al. (2017) highlighted the shifting roles of surveyors, which became evident in the last decades. This changed professional profile affects the academic surveying profession. In addition to the existing curricula offered so far, educational institutions have to extend their study programs to guarantee their graduates' fitness for jobs.

The following learning outcomes document the knowledge, skills, and competencies required for students to fulfil the new surveying roles. The presentations do not claim to be complete, but they should serve as an orientation guide for curriculum developers 
and as a stimulator for discussions in the academic and educational surveying community.

\section{From Measurement of Geometry to Assessment of Thematic Information}

Today, modern remote sensors and up-to-date data processing allow the automatic or semiautomatic assessment of not only geometric but also thematic information about objects. Using high-resolution imaging systems, surveyors are active partners in the development of algorithms and methods to assess diverse information about natural resources. According to Masum et al. (2017), academic education has to guarantee that graduates of surveying programs are able to

- Classify up-to-date remote-sensing platforms and sensor types, and select the appropriate method to gain specific thematic information;

- Describe up-to-date image-processing methods;

- Be trained in the programming of remote-sensing applications; and

- Analyze the quality of results from modern surveying technologies.

\section{From Mapping to Geoinformation-Services}

The implementation of IT led to a paradigm shift in the surveying profession. GISs enable the storage, modeling, visualization, and dissemination of various geodata sets describing physical, ecological, economical, legal, and demographic characteristics of land and other natural resources. Surveyors are experts in producing and providing information about natural resources and their processes. According to Masum et al. (2017), academic education has to guarantee that graduates of surveying programs are able to

- Describe the concepts of GIS;

- Establish and maintain a GIS;

- Identify and describe available GIS applications;

- Develop programming for GIS applications; and

- Understand and explain big data technologies.

\section{From Land Administration to Land Management}

Due to the extension of the legal framework, land management processes have become more complex in recent years. Surveyors collect and process proper data for decision making and provide landowners (or landholders) with expertise and consultancy for land-related activities. Surveyors are actors and supervisors for numerous land-related processes. According to Masum et al. (2017), academic education has to guarantee that graduates of surveying programs are able to

- Demonstrate basic knowledge about natural processes, cultivation of land, environmental management, planning technologies, land reform techniques, and construction processes;

- Describe fundamental approaches to real-property valuation;

- Interpret policies, civics, and ethical fundamentals of land governance;

- Recognize legal issues of land management; and

- Carry out negotiation and mediation activities.

\section{From Application-Driven Data Provider to} Customer-Orientated Consultant and Service Provider In many countries, surveyors and experts from georelated disciplines collect geodata for the National Spatial Data Infrastructure (NSDI) on different topics, using various methods with different accuracies, homogeneities, integrities, and resolutions and with different levels of currency. Surveyors are the administrators and distributors of this information. According to Masum et al. (2017), academic education has to guarantee that graduates of surveying programs are able to
- Recognize appropriate geodetic surveying methods and remotesensing techniques for different geometric data acquisition approaches;

- Demonstrate basic knowledge in neighboring georelated disciplines and analyze their interdependencies with the surveying profession;

- Have general knowledge of transdisciplinary fields (e.g., law and economy); and

- Apply social competence in their activities.

\section{From Local Knowledge to International Expertise}

International cooperation is an essential success factor for achieving the SDGs. Communication, cooperation, and common actions of politicians, professionals, and societies on a global level are the keys to poverty reduction, climate change response, gender equity, and sustainable development. Spatial information management is an essential pillar of good land management and an essential ingredient in meeting the SDGs. Therefore, surveyors are international players in the achievement of globally defined goals. According to Masum et al. (2017), academic education has to guarantee that graduates of surveying programs are able to

- Communicate in their native language and in at least one of the world languages;

- Manifest their willingness for global mobility; and

- Demonstrate transcultural thinking.

\section{Trends in Surveying Education and Teaching}

Developments in information and communication technologies (ICTs), as well as a new didactic and pedagogic awareness, are crucially influencing the methods of knowledge transfer. In addition, efforts to harmonize education on an international level have effects on study programs and teaching methods.

\section{Harmonization and Internationalization}

In 1999, European ministers of education signed the Bologna Declaration to establish a European area of higher education to enable comparable degrees and to establish a system of credits promoting student mobility. The European Credit Transfer and Accumulation System (ECTS) was introduced as a measure to harmonize the workload of students across Europe. This system enables a quantitative comparison between study courses. The qualitative aspects of lectures, modules, or study programs are generally described via learning outcomes, which are statements evidencing what students know, understand, and are able to do on completing the lecture, module, or entire study program.

ECTS and learning outcomes are proper tools to compare quantity and content of study programs and are therefore essential drivers of mobility. ECTS and learning outcomes also can be used for the harmonization of study programs and/or study courses. Nevertheless, a worldwide harmonization of surveying education is not recommended, as land administration varies between countries and so study programs in surveying have to consider local needs.

\section{New Learning Approaches}

Universities and other academic institutions have to incorporate new developments in education. This refers to both teaching tools and educational life cycles. Modern communication technologies strengthen the possibilities of e-learning and minimize the need for personal presence. This creates greater flexibility but also greater responsibility for students, as they must decide when to work on which subject. However, e-learning can never completely replace human interactions.

Modern teaching and learning methods have become a part of surveying education, and they enable optimal knowledge transfer. 
Many courses incorporate the required components for up-to-date knowledge transfer and knowledge exchange: face-to-face lectures, practical (field) work, e-learning tools, and a well-balanced ratio of educational staff and students. Problem-based or project-based education and training are now a part of almost all study programs.

\section{Lifelong Learning}

It is estimated that worldwide knowledge is increasing exponentially. Therefore, the existing concept of self-contained study courses has to be replaced by LLL and continuing professional development (CPD). Without such a concept, employability of graduates will decrease rapidly, as they will not be aware of new developments in their field. LLL or CPD will be found in most educational strategies on international, national, and university levels. However, practical implementation of LLL and CPD on an academic level is marginal. The main reason lies in the availability of human and financial resources.

\section{Capacity Building}

In the surveying profession, specific focus has to be given to capacity building. On a global scale, there is currently a lack of surveyors and land professionals. This lack of surveyors is mainly caused by the decreasing number of students in surveying programs and in a lack of study opportunities in some regions of the world. To overcome this deficit, universities have to develop strategies to bring more students into surveying education and surveying study programs have to be established in countries of the South.

\section{Cooperation}

It is important that all educational institutions cooperate on a national, regional, and international level. Competition between universities is recognized, but jealousy and resentments have to be avoided. Cooperation within the national and international surveying profession will facilitate and strengthen the role and status of surveyors globally.

\section{Surveying Curriculum Development}

Although the surveying curriculum contains a number of core competencies that aim to produce a professional surveyor, concern remains about the additional knowledge, skills, and competencies a surveyor should have. Therefore, the process of continuous development of curriculum is essential for achieving educational goals for the surveying profession. It requires a systematic approach, which should respect the future role of surveyors and required knowledge and skills for the future.

The curriculum development process is complex and has many facets; therefore, it cannot be covered exhaustively by one single model. Although the systematic representation of curriculum development is generally linear and sequential, in practice the process may not be strictly followed. Fig. 1 illustrates how the four compulsory steps progress from one to the next. These steps are essential to successful curriculum development in surveying education and need to be emphasized. Brief descriptions of the steps follow.

\section{Step 1: Evaluate Present Status of the Surveying Curriculum}

The first step is to review the present curriculum structure and learning outcomes. This involves analysis of factors in the context of the present curriculum that is made in order to assess their impact on the surveying profession. This evaluation has to include

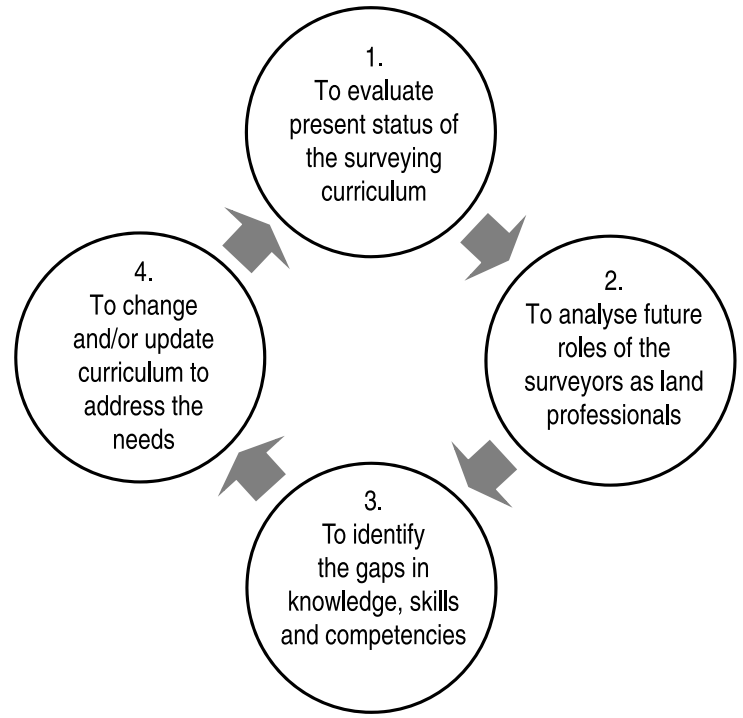

Fig. 1. Surveying curriculum development process.

some form of assessment of learner performance in their practical setting.

\section{Step 2: Analyze Future Roles of Surveyors as Land Professionals}

The rapid development of technology has impacted the surveying profession. Furthermore, global land-related challenges and the importance of the relationship between measurement and land management have added a new dimension to the surveying profession. Therefore, academic institutions must recognize these three major trends and their implications for surveying education.

\section{Step 3: Identify Gaps in Knowledge, Skills, and Competencies}

The surveying profession needs not only robust workforce numbers but also professionals with requisite knowledge, skills, and competencies. Determining the development of a desirable curriculum for surveying education entails identifying and understanding what knowledge is important to have and what skills and competencies are enduring and required. Therefore, the current deficits in knowledge, skills, and competencies that exist in surveyors as land professionals, or the knowledge, skills, and competencies that will be needed over the next decade, should be defined. Based on analysis, an educational philosophy (vision and values) and learning objectives should be set.

\section{Step 4: Change/Update Curriculum to Address Need}

Once the articulated attributes are identified, these should be translated into meaningful learning objectives and learning outcomes. Overall goals and aims of the curriculum should be defined. It is important that courses are organized in accordance with the knowledge, skills, and competencies required in response to the changing roles of surveyors. In order to successfully implement the new curriculum, teaching methods should be selected carefully and should provide the opportunity for life-long learning and application of knowledge in practice. New educational approaches and tools-problem-based learning, outcome-based learning, blended learning, experimental learning, business models, stadium fundamentals, crossroads (Groenendijk 2009)—can be applied. 
As discussed in previous sections, one topic of consensus arising from discussions among land professionals is that the conventional surveying education system often fails to adequately prepare future surveyors with the essential skills necessary to respond to changing needs. There is an urgent need to transform surveying education to respond to the challenges of the new era. Restructuring of curricula has been called for to ensure that surveying education is more robust, rigorous, and relevant to better prepare land professionals.

\section{Surveying Education and Curriculum in Europe: Fitting into a New Dimension}

Surveying education has become a crucial arena for asserting a broader vision for a new surveying society. One can never downplay the fact that surveyors are evidently dealing with global landrelated challenges, creating a demand for a new curriculum structure that can function in the broader scope of the surveying profession. With regard to changes in the surveying profession, there have been many discussions about what should be taught and what should be left out. Such discussions are also reflected in curricula changes and the discourse of course choice, which emphasize the fact that the surveying profession is increasingly seen as a land profession.

The next section briefly reviews some of the major international trends in surveying curricula which have led to discussions of the present and future structure of the surveying curriculum.

\section{Historical Review}

Though surveying as a profession has its roots in the distant past, formal university-level educational programs started about the beginning of the nineteenth century with the program at the Ecole Polytechnique in Paris, France, and the Polytechnical School in Karlsruhe, Germany (Draheim 1974, quoted in National Academy of Science 1978, p. 71). According to Konecny (2002), at the University of Hannover the first surveying course was given in 1831 within civil engineering. Many European countries [e.g., the Netherlands, Austria, Switzerland, Poland, Czechoslovakia (now Czech Republic and Slovakia), Yugoslavia (now Serbia, Croatia, and Slovenia), Denmark, Sweden, Finland, Norway and Hungary] initiated surveying degree programs before the beginning of World War II.

Usually academic programs in surveying were developed in civil engineering departments. Surveyors in Central and Eastern Europe considered this attitude detrimental to the vigorous evolution of the profession of surveying and mapping (National Academy of Science 1978). Therefore, around 1920 they broke away from civil engineers to establish independent surveying and mapping departments at many universities. In parallel with technological developments, especially after the World War II, surveying and geodesy programs were restructured (Ipbuker 2010).

Much of the growth in surveying education has occurred recently and has cut across the lines of traditional surveying. The study topics in geodetic, surveying, other spatial and land studies have changed and broadened during the last decades (Lisec et al. 2009). These changes reflect new technological developments and needs of society where the emphasis is on environmental sciences, land management, urban planning, natural resource management, and the like (Potůčková 2006). Therefore, the contemporary scope of surveying education is more complex, larger, and more dynamic than before, requiring more expertise and skills; this trend will continue in the future.

Allan (1995) was the first significant work describing different university programs in surveying (Virrantaus and Haggrén 2002).
Based on analysis of university programs at the bachelor's and master's levels in 17 countries in Western Europe, Allan identified six main models: geodetic sciences, engineering, hydrographic, cadastre, planning, and real estate. According to Enemark (2002), these curricula make up the areas of measurement science and land management supported by a strong paradigm of spatial information management. Based on Allan (1995) and Mattsson et al. (2016) compared surveying curricula in various European countries. They proposed three main specializations: measurement and GIS, property rights and land cadastre, and land use planning and development.

\section{Up-to-Date Inventory}

In this study, 15 university programs at the bachelor's and master's levels in 12 European countries were investigated. Based on the categories of Enemark (2002) and Mattsson et al. (2016), four main categories could be identified (Tables 2 and 3): measurement science, spatial information management/technical, land management, and environmental management. however, environmental management receives less priority at the master's level than at the bachelor's level.

The results of the analysis show that the western surveying curriculum is steeped in a particular set of structures that are different from traditional surveying education. Knowledge, skills, and competencies, which are prioritized in the curricula, moved from monodisciplinary fields to multidisciplinary fields. The courses focus on employability, transferable skills, and practical learning. Given the multidisciplinary nature of the curriculum, surveying students gain transferable competencies and an ability to work in a solutionoriented manner.

\section{The Future: Common Approach}

The surveying curriculum is facing major changes in the future. What was formerly the case is still valid now: a university education must provide graduates intellectual versatility in which graduation is only the first step in a lifelong learning process, as technologies develop further (Konecny 2002). Central to the success of the profession across the world will be the capability of surveyors to demonstrate enhanced managerial and leadership skills in addition to specialist technical/professional knowledge (Kennie and Enemark 1996). Professional success demands different abilities: negotiation, conflict resolution, leadership, organizational, and managerial skills. Therefore, professional skills development courses can offer the ability to think independently in strategic, systematic, conceptual, creative, and critical ways and to make more effective decisions.

Fig. 2 is an example future surveying curriculum that will meet the changing requirements of surveying education. In a first step, learning outcomes can be formulated that cover the objective of the curriculum and meet changing requirements in the surveying profession. In a second step, the contents of the curriculum are developed according to the proposed thematic groups-measurement science, spatial information management, land management, and environmental management. To achieve the goal of cross-cutting competencies, professional skills development courses are included in the curriculum. Master's programs focus on specific thematic fields and enable a variety of tracks, which can be tailored to national, regional, and/or global challenges.

\section{Conclusions and Recommendations}

In looking to the future of the surveying profession, educational institutions should endeavor to meet the new requirements of the surveying profession by adapting curricula and by providing CDP 
Table 2. Bachelor's-level surveying curricula at European universities

\begin{tabular}{|c|c|c|c|c|c|c|c|c|c|c|}
\hline \multirow[b]{2}{*}{ Main areas } & \multirow[b]{2}{*}{ Course } & \multicolumn{9}{|c|}{ Universities } \\
\hline & & TUM & TU WIEN & ETH & UPC & DIT & UEL & MUAS & HIG & KUT \\
\hline \multirow[t]{3}{*}{ Measurement science } & $\begin{array}{l}\text { Land surveying/surveying instruments and methods/ } \\
\text { surveying engineering }\end{array}$ & & & & $\mathrm{x}$ & & $\mathrm{x}$ & $\mathrm{x}$ & $\mathrm{x}$ & $\mathrm{x}$ \\
\hline & Geodesy/geodetic instruments/geodetic surveying & $\mathrm{x}$ & $\mathrm{x}$ & $\mathrm{x}$ & $\mathrm{x}$ & $\mathrm{x}$ & & $\mathrm{x}$ & $\mathrm{x}$ & \\
\hline & Geomatics & $\mathrm{x}$ & $\mathrm{x}$ & & $\mathrm{x}$ & & $\mathrm{x}$ & & $\mathrm{x}$ & $\mathrm{x}$ \\
\hline \multirow{7}{*}{$\begin{array}{l}\text { Spatial information } \\
\text { management/technical }\end{array}$} & GIS & $\mathrm{x}$ & $\mathrm{x}$ & $\mathrm{x}$ & $\mathrm{x}$ & $\mathrm{x}$ & $\mathrm{x}$ & $\mathrm{x}$ & $\mathrm{x}$ & $\mathrm{x}$ \\
\hline & Photogrammetry & $\mathrm{x}$ & $\mathrm{x}$ & $\mathrm{x}$ & $\mathrm{x}$ & & & & $\mathrm{x}$ & $\mathrm{x}$ \\
\hline & Remote sensing & $\mathrm{x}$ & $\mathrm{x}$ & & $\mathrm{x}$ & $\mathrm{x}$ & & & $\mathrm{x}$ & $\mathrm{x}$ \\
\hline & Cartography & $\mathrm{x}$ & $\mathrm{x}$ & $\mathrm{x}$ & $\mathrm{x}$ & & & $\mathrm{x}$ & $\mathrm{x}$ & $\mathrm{x}$ \\
\hline & Image processing & $\mathrm{x}$ & $\mathrm{x}$ & $\mathrm{x}$ & $\mathrm{x}$ & & & & & \\
\hline & Information technology & $\mathrm{x}$ & $\mathrm{x}$ & $\mathrm{x}$ & & $\mathrm{x}$ & & $\mathrm{x}$ & & \\
\hline & $\begin{array}{l}\text { Spatial data analysis/spatial information application/ } \\
\text { land information system/geo-information }\end{array}$ & & $\mathrm{x}$ & & $\mathrm{x}$ & $\mathrm{x}$ & & $\mathrm{x}$ & & $\mathrm{x}$ \\
\hline \multirow[t]{8}{*}{ Land management } & $\begin{array}{l}\text { Land development and urban development/built } \\
\text { environment/smart cities }\end{array}$ & $\mathrm{x}$ & & & $\mathrm{x}$ & & $\mathrm{x}$ & & & \\
\hline & Land management & $\mathrm{x}$ & & $\mathrm{x}$ & & $\mathrm{x}$ & $\mathrm{x}$ & & & \\
\hline & Cadastre/land administration & & $\mathrm{x}$ & & $\mathrm{x}$ & & $\mathrm{x}$ & $\mathrm{x}$ & & $\mathrm{x}$ \\
\hline & Real estate management & & & & & & & $\mathrm{x}$ & & $\mathrm{x}$ \\
\hline & Property valuation & $\mathrm{x}$ & & & & & & $\mathrm{x}$ & & $\mathrm{x}$ \\
\hline & Planning/spatial planning/local planning & $\mathrm{x}$ & $\mathrm{x}$ & $\mathrm{x}$ & & $\mathrm{x}$ & & $\mathrm{x}$ & $\mathrm{x}$ & $\mathrm{x}$ \\
\hline & Traffic planning/transport infrastructure & & & $\mathrm{x}$ & & & & $\mathrm{x}$ & & $\mathrm{x}$ \\
\hline & Urbanism and regional planning & & & & $\mathrm{x}$ & & & & & \\
\hline \multirow[t]{2}{*}{$\begin{array}{l}\text { Environmental } \\
\text { management }\end{array}$} & $\begin{array}{l}\text { Environmental geography/ecology/environmental } \\
\text { economics }\end{array}$ & & $\mathrm{x}$ & $\mathrm{x}$ & & & & & $\mathrm{x}$ & \\
\hline & $\begin{array}{l}\text { Environmental planning and engineering/ } \\
\text { environmental impact assessment/environmental } \\
\text { protection }\end{array}$ & & & & $\mathrm{x}$ & & & $\mathrm{x}$ & & $\mathrm{x}$ \\
\hline
\end{tabular}

Note: TUM = Technical University of Munich, B.Sc. in geodesy and geoinformation; TU WIEN = Technische Universität Wien (Austria), B.Sc. in geodesy and geoinformation; ETH = ETH Zurich, B.Sc. in geomatic engineering and planning; UPC = Universitat Politecnica de Catalunya (Spain), B.Sc. in geoinformation and geomatics engineering; DIT = Dublin Institute of Technology, B.Sc. in geomatics (surveying and mapping); UEL = University of East London, B.Sc. in surveying and mapping services; MUAS = Metropolia University of Applied Sciences, Helsinki, B.Sc. in land surveying; HIG = University of Gävle (Sweden), B.Sc. in geomatics; KUT = Kielce University of Technology (Poland), B.Sc. in geodesy and cartography; and $\mathrm{x}=$ course available at university.

Table 3. Master's-level surveying curricula in European universities

\begin{tabular}{|c|c|c|c|c|c|c|c|}
\hline \multirow[b]{2}{*}{ Main areas } & \multirow[b]{2}{*}{ Course } & \multicolumn{6}{|c|}{ University } \\
\hline & & LUH & AAU & ITC & $\mathrm{LU}$ & $\mathrm{AU}$ & $\mathrm{UG}$ \\
\hline \multirow[t]{3}{*}{ Measurement science } & Land surveying/surveying instruments and methods/surveying engineering & & $\mathrm{x}$ & & & $\mathrm{x}$ & $\mathrm{x}$ \\
\hline & Geodesy/geodetic instruments/geodetic surveying & $\mathrm{x}$ & $\mathrm{x}$ & & & $\mathrm{x}$ & $\mathrm{x}$ \\
\hline & Geomatics & & $\mathrm{x}$ & $\mathrm{x}$ & $\mathrm{x}$ & $\mathrm{x}$ & $\mathrm{x}$ \\
\hline \multirow{7}{*}{$\begin{array}{l}\text { Spatial information } \\
\text { management/technical }\end{array}$} & GIS & $\mathrm{x}$ & & & $\mathrm{x}$ & $\mathrm{x}$ & $\mathrm{x}$ \\
\hline & Photogrammetry & $\mathrm{x}$ & & & & $\mathrm{x}$ & \\
\hline & Remote sensing & $\mathrm{x}$ & & o & $\mathrm{x}$ & $\mathrm{x}$ & \\
\hline & Cartography & & & & & & \\
\hline & Image analysis/processing & & & $\mathrm{x}$ & & $\mathrm{x}$ & \\
\hline & Information technology & & $\mathrm{x}$ & $\mathrm{x}$ & $\mathrm{x}$ & & \\
\hline & $\begin{array}{l}\text { Spatial data analysis/spatial information application/land information } \\
\text { system/geoinformation }\end{array}$ & $\mathrm{x}$ & & $\mathrm{x}$ & $\mathrm{x}$ & $\mathrm{x}$ & $\mathrm{x}$ \\
\hline \multirow[t]{9}{*}{ Land management } & Land development and urban development/built environment/smart cities & & & & & & \\
\hline & Natural resource management/land management & $\mathrm{x}$ & $\mathrm{x}$ & o & & & \\
\hline & Land tenure and land policy & o & & & & & \\
\hline & Cadastre/land administration & & & o & & & $\mathrm{x}$ \\
\hline & Real estate management & $\mathrm{x}$ & & & & & \\
\hline & Property valuation & & & & & & \\
\hline & Planning/spatial planning/local planning/urban planning & & $\mathrm{x}$ & o & & & \\
\hline & Traffic planning/transport infrastructure & & & & & & \\
\hline & Urbanism and regional planning & & & & & & \\
\hline \multirow{2}{*}{$\begin{array}{l}\text { Environmental } \\
\text { management }\end{array}$} & Environmental geography/ecology/environmental economics & & & & o & & \\
\hline & $\begin{array}{l}\text { Environmental planning and engineering/environmental impact assessment/ } \\
\text { environmental protection }\end{array}$ & & & o & o & & \\
\hline
\end{tabular}

Note: o = Specialized/elective courses; LUH = Leibniz Universität Hannover (Germany), M.Sc. in geodesy and geoinformatics; AAU = Aalborg University (Denmark), M.Sc. in surveying and mapping; ITC = University of Twente (the Netherlands), M.Sc. in geoinformation science and earth observation; LU = Lund University (Sweden), M.Sc. in geomatics; AU = Aalto University (Finland), M.Sc. in geoinformatics; UG = University of Glasgow, M.Sc. in geospatial and mapping sciences; and $\mathrm{x}=$ course available at university. 


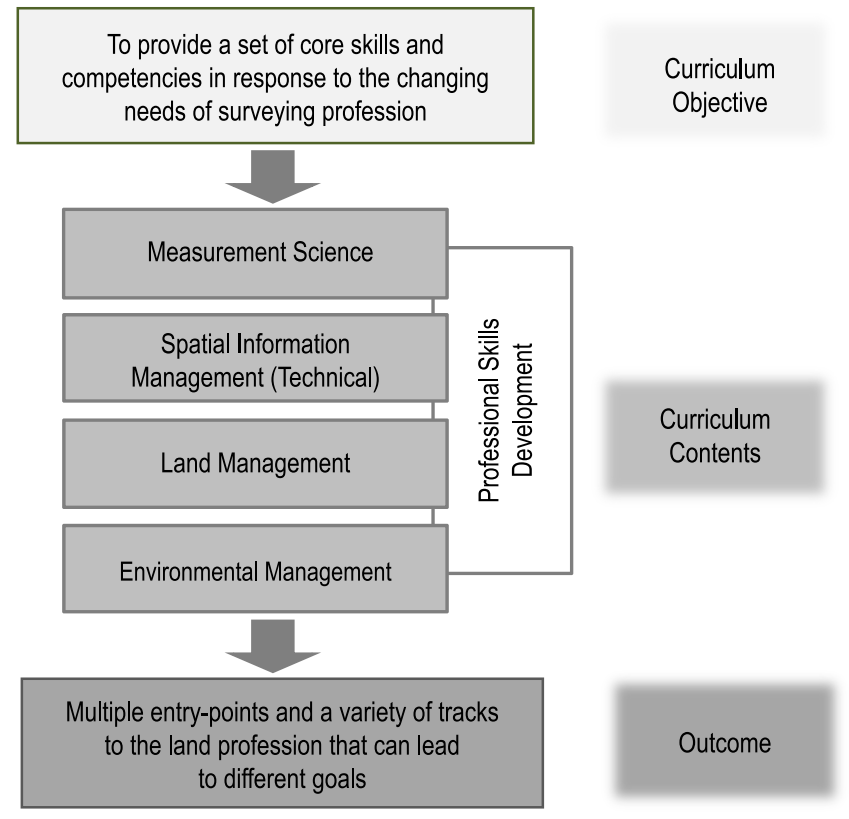

Fig. 2. Future structure of the surveying curriculum.

and LLL (Masum et al. 2017). In many developing countries, conventional surveying education is still current at this time. To meet international industry and corporate demand, geomatics professionals increasingly need to attain specialties and exhibit competencies beyond traditional expectations. Thus programs of education need to prepare innovative graduates to work with high competence, using specialized skills and deep knowledge, as producers, managers, and users of geospatial information in many related disciplines. Efforts should be directed toward establishing a common structure with competency frameworks as global standards. Focus should shift from a surveying knowledge-based curriculum to surveying knowledge as one part of a curriculum. It is therefore necessary to adopt the following measures:

- Surveying curricula need to be sufficiently flexible to cope with the changing pattern of surveying professions.

- Curricula should provide multiple entry points to the land profession and a variety of tracks that can lead to different goals.

- Long-term feedback mechanisms must be provided for curriculum development.

It is also important to have a well-defined sense of future direction and a clear plan including internationalization and networking, new teaching approaches, and ways to achieve the new teaching approaches. In this respect, the blended learning environment is most effective for supporting experiential and situated learning by combining different disciplinary models with different media to create optimum teaching and learning programs (Bersin 2004).

This study recommends internationalization and networking of surveying as institutional measures to enhance and facilitate a truly international surveying community, which can prepare students to recognize opportunities provided by interconnectivity in a globalized world. A worldwide network of educational institutions can further drive interest in the surveying profession through joint programs for students (Masum et al. 2017). In acknowledging that surveying education systems vary in different countries, the need for partnerships with an objective to deliver a consistent global educational standard (i.e., ECTS as a quantitative measure for study courses and learning outcomes as a tool for describing the contents and quality) should be recognized.

\section{References}

ABET (Accreditation Board for Engineering and Technology). 2017. "ABET engineering accreditation commission. Criterial for accrediting engineering programs." Accessed March 1, 2018. http://www.abet.org /wp-content/uploads/2018/02/E001-18-19-EAC-Criteria-11-29-17.pdf.

Allan, A. L. 1995. The education and practice of the geodetic surveyor in Western Europe. 3rd ed. 1-159. Brussels, Belgium: Council of European Geodetic Surveyors.

American Congress on Surveying and Mapping. 1978. Definitions of surveying and associated terms. ASCE Manuals and Rep. on Engineering Practice, 34. Reston, VA: ASCE.

Bersin, J. 2004. The blended learning book: Best practices, proven methodologies, and lessons learned. San Francisco: Pfeiffer.

Bucharest Communique. 2012. "Making the most of our potential: Consolidating the european higher education area." Accessed March 12, 2018. http://www.ehea.info/media.ehea.info/file/2012_Bucharest/67/3 /Bucharest_Communique_2012_610673.pdf.

Campbell, R. 1747. The London tradesman. London: T. Gardner.

ECOSOC (United Nations Economic and Social Council). 2017. "United Nations experts in global geospatial information management." Accessed January 17, 2018. http://ggim.un.org/.

Enemark, S. 2002. "Innovation in surveying education." Global J. Eng. Educ. 6 (2): 153-159.

Enemark, S., and I. Williamson. 2004. "Capacity building in land administration—A conceptual approach.” Surv. Rev. 37 (294): 639-650. https://doi.org/10.1179/sre.2004.37.294.639.

FAO (Food and Agriculture Organization). 2012. "Voluntary guidelines on the responsible governance of tenure of land, fisheries, and forests in the context of national food security." Accessed October 30, 2017. http://www.fao.org/docrep/016/i2801e/i2801e.pdf.

FIG (International Federation of Surveyors). 2008. FIG statutes, internal rules and guidelines, 66. Copenhagen, Denmark: FIG.

Fisher, A. 2015. "Critical role for geospatial data in advancing sustainable development goals." Accessed May 8, 2015. http://blogs.ei .columbia.edu/2015/05/08/sdg_geospatial_data2015/.

Groenendijk, L. 2009. "Experience based learning and e-learning: A perfect combination." In Proc., ISPRS Workshop on E-learning Tools, Techniques and Applications, 36-41. Potsdam, Germany: International Society for Photogrammetry and Remote Sensing.

Heipke, C. 2010. "Crowdsourcing geospatial data." ISPRS J. Photogramm. Remote Sens. 65 (6): 550-557. https://doi.org/10.1016/j.isprsjprs.2010 .06 .005 .

HODAI (Hub of Data and Initiatives). 2016. "The crucial list." Accessed January 9, 2018. http://www.hodai.org.

Ipbuker, C. 2010. "The reason of changing the name of geomatics." In Proc., 24th FIG Congress. Copenhagen, Denmark: International Federation of Surveyors.

Kennie, T., and S. Enemark. 1996. CPD-Continuing professional development and its future promotion within FIG. FIG Publication No. 15. Copenhagen, Denmark: International Federation of Surveyors.

Konecny, G. 2002. Recent global challenges in geomatics education. Accessed February 9, 2018. http://www3.inpe.br/unidades/cep/atividadescep /isprs/cd-rom/Papers_Titulos/019.pdf.

Labi, S. 2014. Introduction to civil engineering systems: A Systems Perspective to the Development of Civil Engineering Facilities. New York: Wiley.

Lemmens, M. 2011. Geo-information: Technologies, applications and the environment. Dordrecht, Netherlands: Springer.

Lisec, A., S. Drobne, D. Petrovic, and B. Stopar. 2009. "Professional competences of surveying (geodetic) engineers." In Proc., Professional Education 2009-FIG Int. Workshop. Copenhagen, Denmark: International Federation of Surveyors.

Masum, F., L. Groenendijk, R. Mansberger, and A. Martin. 2017. "Enhancing the role of surveyors: Bridging the gap between demands for and supply of professional education." In Proc., FIG Working Week 2017. Copenhagen, Denmark: International Federation of Surveyors. 
Mattsson, H., G. Lindner, and, R. Mansberger. 2016. Higher education on land management and land administration. ELFRUS-Elaboration of Qualification Framework for Land Management Studies at Russian Universities. Brussels, Belgium: European Union.

National Academy of Science. 1978. Geodesy: Trends and prospects, Washington, DC: National Academy of Science.

Potůčková, M. 2006. "Trends in geoinformatics education." Geinformatics, FCE CTU 1: 35-43.

Rayner, S. A., and J. V. Buley. 1965. Surveying in Queensland. Occupational Survey No. 5. St. Lucia, Australia: University of Queensland Press.
UN (United Nations). 2017. "United nations development goals.” Accessed December 10, 2017. http://www.un.org/sustainabledevelopment /sustainable-development-goals.

Virrantaus, K., and H. Haggrén. 2002. "FIG educational portal—A method and user interface to manage surveying educational curricula." In Proc., 22nd FIG Congress. Washington, DC: International Federation of Surveyors.

WEF (World Economic Forum). 2017. "What are the biggest global challenges?" Accessed December 6, 2017. https://www.weforum.org /agenda/2016/01/what-are-the-10-biggest-global-challenges. 